Omni-Akuatika, 15 (1): 103-109, 2019
ISSN: 1858-3873 print / 2476-9347 online
Research Article
journal homepage: htt://ojs.omniakuatika.net

\title{
Fish Aggregation Pattern on Red-Blue-Green Light Emitting Diode (RGB-LED) Light in Static Lift Net
}

\author{
Sugandi ${ }^{*}$, Ronny Irawan Wahju ${ }^{2}$, Mochammad Riyanto $^{2}$, Sumardi $^{3}$ \\ ${ }^{1}$ Student of Marine Fisheries Technology Study Program, IPB Postgraduate School, Indonesia. \\ ${ }^{2}$ Department of Fisheries Resources Utilization, Faculty of Fisheries and Marine Science, IPB University \\ Dramaga Campus. Bogor 16680, West Java, Indonesia. \\ ${ }^{3}$ Electrical Engineering Study Programs. Faculty of Engineering, Tangerang Muhammadiah University.
} Tangerang, Banten, Indonesia.

"Corresponding author: kepadagandi@gmail.com

Received 10 July 2018; Accepted 19 April 2019; Available online 31 May 2019

\begin{abstract}
The Red-Blue-Green Light Emitting Diode (RGB-LED) light used in the static lift net can manipulate fish behavior to attract, approach and be concentrated in the lighting area. The purpose of this study is to determine the use of the RGB-LED light intensity with pulse width modulation, value for gathering fish and changing patterns of schooling fish's movement. Seven treatments with changes in PWM values were the initial conditions, 250, 195, 145, 9520 and 5 PWM. The methods were by using Hydro-acoustic sonar $360^{\circ}$ and ImageJ analysis used to determine the schooling fish's area in horizontal and vertical by dividing the center zone, main zone, influence zone, and shadow zone. Results of the visualization image of schooling fish as the target fish group visualized by horizontally and vertically. It has the longest duration of 90 ' and 250 PWM has a time duration of 10' shows the difference in the area of schooling fish in four zones. 195, 145 and 95 PWM with each time duration of 10 ' dominant schooling fish were in the main zone and influence zone, the lowest two light intensities of PWM values were 5 and 20 , there are three zones namely center zone, main zone, and shadow zone, schooling fish were increasing with movement pattern by revolving the light source at shadow zone. The approached fish were forming schooling fish because they were attracted to light, with changes in the PWM value that can model the movement patterns of schooling fish.
\end{abstract}

Keywords: Hydro-acoustic, sonar $360^{\circ}$, gather, zone, PWM.

\section{Introduction}

RGB-LED light is an innovation of technology development of fish attractor lamp in static lift net (SLN), using a combination of different colors light of Red, Green, and Blue of High Power Led (HPL) with special designed become RGB-LED. Blue, green and red light, are easily stimulated by target catch of lift net and tend to move by approaching the light source (Takahasi et al. 2018; Flare et al. 2016; Bao 2014). According to Brown et al. (2014); Loupatty. (2012), revealed that by using the colors of blue, yellow, green, red and white from the LEDs produces a difference in fish catch. Fish in lighting areas tend to form school formations and normal feeding interactions (Mekdara et al, 2018; Im et al., 2018; Pena et al., 2018).

SLN using light to manipulate fish behavior in movement patterns, migration, and fish interactions (Pulgar et al., 2019; Chairunnisa et al., 2017). The approaching fish and concentrated to light sources have a spatial and temporal distribution patterns (Fujaya 2002; Urbasa et al. 2015). The success of fishing in SLN is determine from the use of the light intensity level, oceanographic factors and the hauling time (Brown et al., 2016; Ramadan et al., 2018; Palawe et al., 2019).

The observations of fish behavior that occurs in the RGB LED lighting area is very 
difficult to detect visually. The hydro-acoustic approach is can be used to detect objects includes schooling fish in real-time and in-situ (Penggabean, 2011), without disturbing the fish habitat (Dufour et al., 2018). The hydro-acoustic method is widely used to monitor fish, the distribution of fish movements and the fish abundance in the waters (Parra et al., 2017; Fore, et al., 2017). The hydro-acoustic method is able to distinguish objects other than fish such as seaweed, and base substrate by developing the value of the algorithm (Manik et al., 2014; 2015).

The response of fish attraction to LED light is influenced by light intensity, irradiation time and water conditions. Use of RGB-LED light with control of light intensity using a Pulse Width Modulation (PWM) value system as the main fishing tools in lift net fishing. RGB-LED lighting still has problems in utilizing changes in PWM values to pay attention to the fish behavior of approaching, gathering and concentrated in light. The setting of RGB-LED light on the presence of fish needs to be analyzed with the hydro-acoustic method approach so that it can determine the model of fish movement, presence and effective hauling time. The purpose of this assessment is to determine the use of RGB-LED light intensity based on fish behavior such as changes in fish movement patterns, presence, and fish gathering.

\section{Materials and Methods}

\subsection{Time and locations}

The research was conducted in October 2018 during the dark phase of the moon, in the waters of the Bokor Island with the coordinate position of $\left(05^{0} 56^{\prime} 593^{\prime} S\right.$ - $\left.106^{0} 37^{\prime} 557^{\prime} E\right)$, Seribu Islands, North Jakarta (Figure 1).

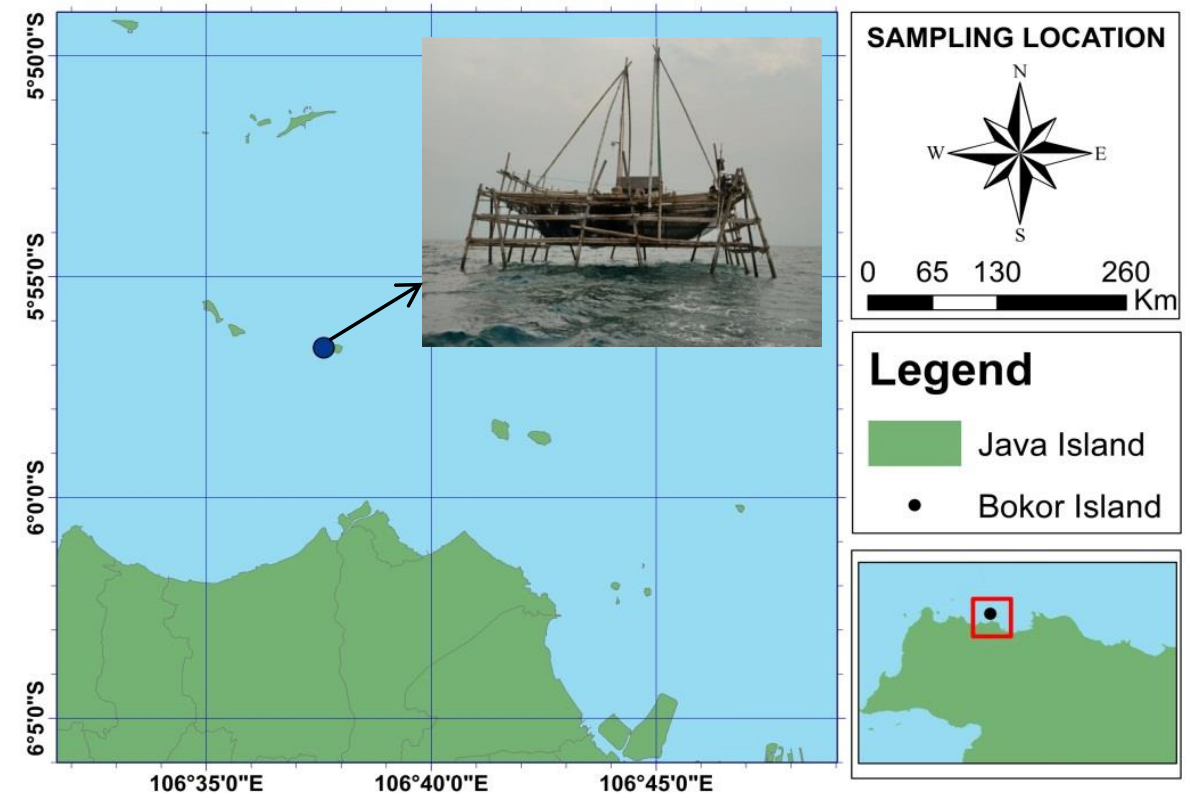

Figure 1. Map of research location in Seribu Island, North Jakarta

\subsection{Data analysis method}

Observations was started at 6:15 p.m., setting until hauling has duration of 140 minutes divided into initial conditions (IC) of 90', 250 PWM of 10', 195 PWM of 10', 145 PWM of 10', 95 PWM of 10', 20 PWM 10' and 5 PWM of 10'. The research method was conducted by experimental fishing on the lift net using RGBLED light.

Observation of fish behavior with sonar hydro-acoustic devices $\left(360^{\circ}\right.$ imaging sonar and side imaging sonar) mounted on the center of lift net. The working principle of sonar $360^{\circ}$ detects the movement of schooling fish which are approaching to the light source horizontally with an area within $12 \mathrm{~m}$ while side imaging sonar (fish finder) has a two-way system (dual beam) to detect the depth of schooling fish movement vertically with a distance of $21 \mathrm{~m}$ depth by frequency of $800 \mathrm{kHz}$.

The collected data were the image of schooling fish including the presence of schooling fish by zones consisting of the center zone (CZ), main zone (MZ), influence zone (IZ) and shadow zone (SZ) and fish movement patterns under RGB-LED lighting. The schooling fish image from the hydro-acoustic 
device was produced vertically and horizontally. Image data of schooling fish were tabulated based on time and light intensity by using a different PWM value.

2.3. Data analysis of schooling fish estimation from hydro-acoustic devices

The tabulated image data of schooling fish then analyzed descriptively with processing image techniques. Image-J is an open source software analysis that has macro-tools that are used to process the data and analyzing a patterned digital image (Dey et al., 2011). The analysis parameters were using the fish presence by vertical and horizontal preference.

Image data of schooling fish were distributed at each depth and then the technique of measuring area was carried out on the light distribution vertically and horizontally. Characterization of proportions, in general, can be known by Image-J analysis (Zielkea et al. 2016). Measure the estimated proportions of schooling fish from digital images, by marking areas of proportion and object points (Alhosseini et al., 2011):

$\mathrm{P}=\left(\frac{n}{N}\right) \times 100 \%$

Descriptions:

$$
\begin{aligned}
& n=\text { represents the white image } \\
& \mathrm{N}=\text { total image in the image } \\
& \mathrm{P}=\text { total area of proportion }
\end{aligned}
$$

2.4. Analysis of RGB-LED light distribution patterns in the water medium

The light intensity of RGB LED with PWM is a way to manipulate pulse signal width in a period through the provision of measurement signal waves using radians meters (ILT500) and modeled with Surfer 13 software. Measuring the light intensity was performed vertically and horizontally based on the light intensity of different RGB-LED lights.

\section{Results and Discussion}

RGB-LED light intensity changes from the maximum to minimum intensity by reducing the PWM value that consists of 250 PWM, 195 PWM, 95 PWM, 20 PWM, and 5 PWM. The results of the compilation of the estimated images of schooling fish by light distribution with different PWM.

Hydro-acoustic fish identification is an analysis to identify fish with sound waves in the area and time (Figure 2). The hydro-acoustic device is consists of sonar $360^{\circ}$ and side imaging sonar.

Acoustic power radiated to detect fish (Celi, et al., 2016). The noise of the generator engine on lift net influences the cleanliness of the scanning display in estimating the schooling fish in the form of an image on the hydroacoustic device display. The noise from the ship reduces its sensitivity for detecting fish (Smott el al., 2018).

The appearance of schooling fish images (Figure 2) generally has histograms that tend to be around dark. Processing image by thresholding image is to distinguish between objects and background (Faizah K., 2017). The image provides a mean to measure membrane proportions in a faster and more accurate way.

The abundance of schooling fish images was determined based on the observation time interval with PWM value changes. Maximum light intensity conditions with a value of 250 PWM has the image of schooling fish spreading by keeping a distance, but at minimum conditions indicate changes in the formation of schooling fish image by near to the light source. The temporal abundance of fish will increase fish swimming movements consistently ( Rand, et al., 2014). According to Rieucau et al., (2016) the dynamics of schooling fish spread rapidly in environmental conditions when predatory fish came.
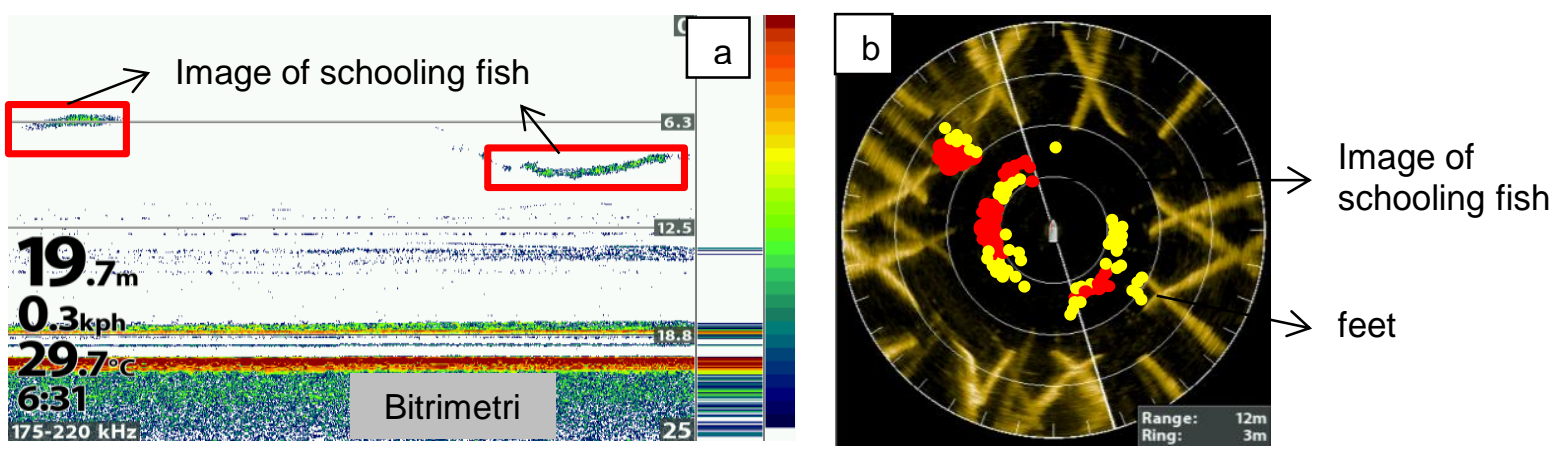

Figure 2. Image of schooling fish from Sonar $360^{\circ}$ hydro-acoustic device. (a). Side imaging sonar (b). Imaging sonar 
Hydro-acoustic sonar $360^{\circ}$ device observes differences in the presence and pattern of schooling fish horizontally and vertically. An interesting phenomenon of light intensity changes using PWM value system where fish behavior that always maintains a distance, gather and move around by rotating pattern on the light source (Cahyadi and You., 2016), strategies for using light can affect fish density and fish biomass in certain areas (Gou et al., 2019)

Horizontally, the movement pattern of schooling fish revolves around the center of light with a certain distance and certain time will increase the fish. Whereas vertically, the movement pattern of schooling fish with high light intensity of 250 PWM resulting the fish at 14 - $18 \mathrm{~m}$ depth in the influence zone which was a wide-spread light, at medium light intensity the pattern of schooling fish moves up to the surface, at low light intensity with a value of 20 PWM was the optimum intensity of fish, because the movement pattern of schooling fish was close to the center of light and the number is increasing, so when the hauling process the percentage of escaped fish was very small. External factors other than light intensity changes is the movement pattern change of schooling fish in the presence of predatory fish which attacking the targeted fish catch of lift net (Williamson et al., 2019).

The presence of schooling fish was closely related to its optimum light intensity. The difference in light intensity horizontally with an area of $12 \times 12 \mathrm{~m}$ of lift net by the initial conditions, 250, 195, 145, 95, 20 and 5 PWM will affect the proportion of schooling fish area. Differences in different light intensities resulting fish species which sensitive to the light color (Nabiu et al., 2018).

The result of sonar $360^{\circ}$ shows the proportion of the schooling fish presence in each zone horizontally with light intensity using different PWM values. In the $\mathrm{CZ}$, one of seven treatment shows a proportion of dominant schooling fish at $95 \mathrm{PWM}$ value of $34 \%$. MZ at 195 PWM value of $54 \%$. In IZ the initial conditions of $46 \%$, the initial condition is a stage to gather the fish with the longest duration in the lift net operation (Himan et al., 2018), but at 20 and 5 PWM there was no influence zone because of the generated light was out of the net width. SZ at 5 PWM was equal to $42 \%$. (Figure 3).

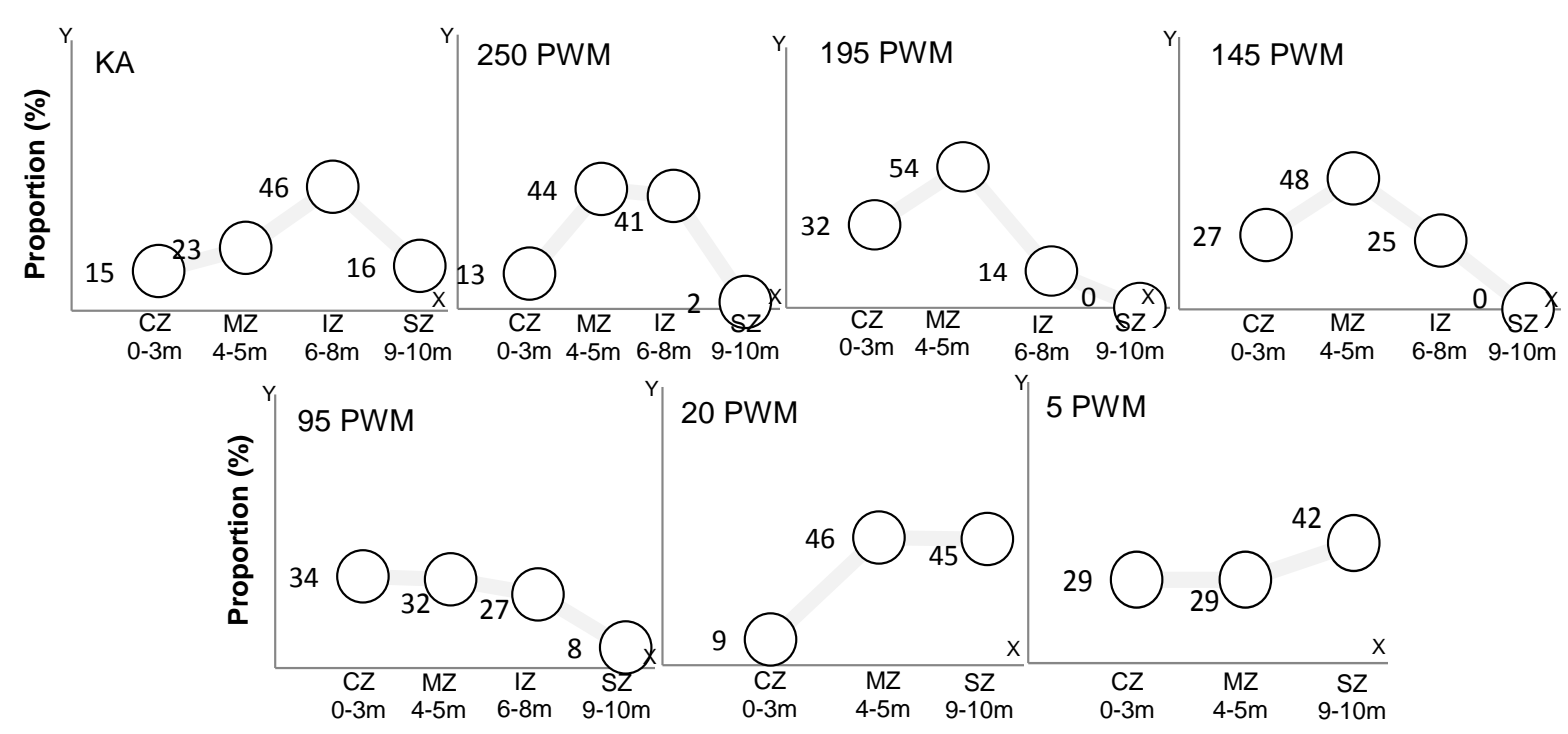

Figur 3. The presence of schooling fish based on light intensity horizontally 


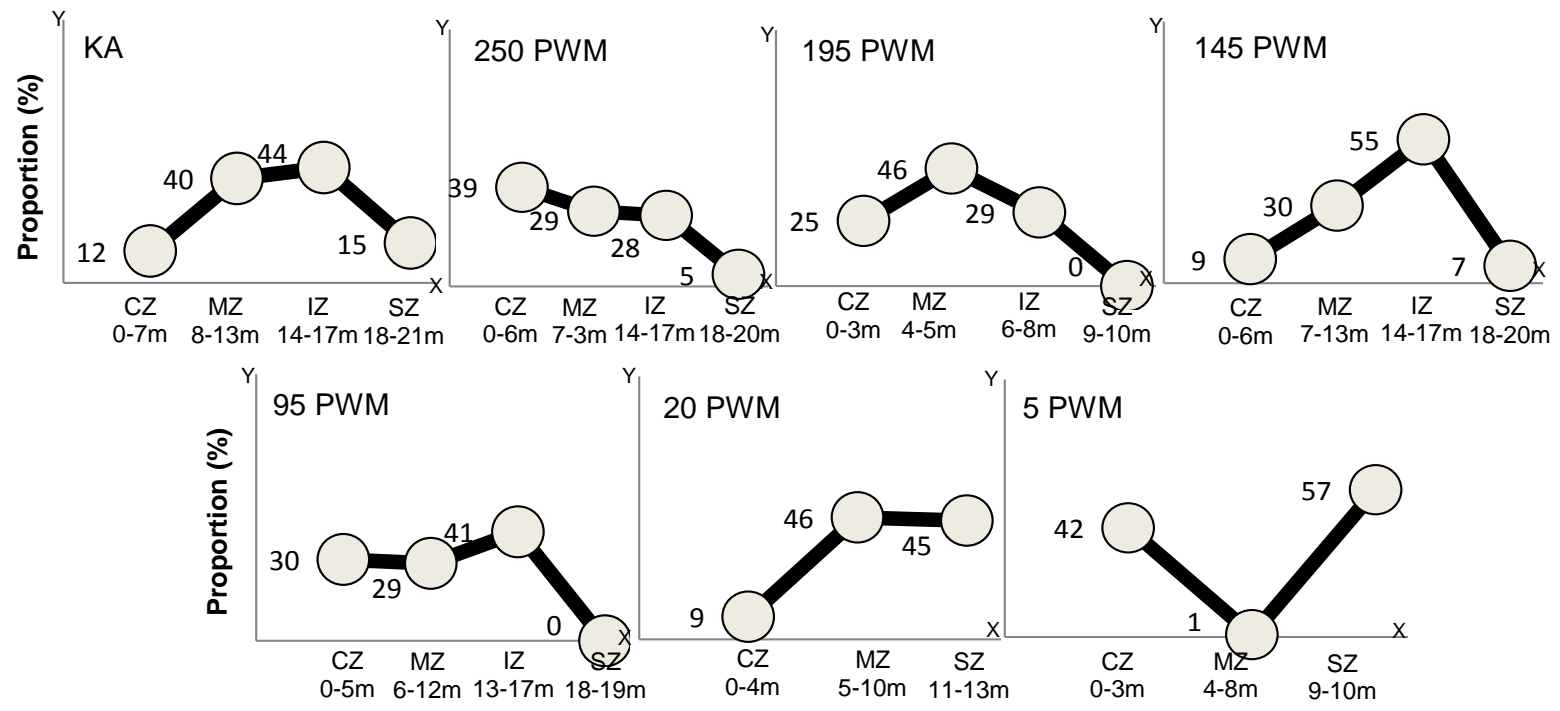

Figure 4. Presence of schooling fish based on light intensity vertically

The emergence of schooling fish vertically around the fishing area is attracted to light. According to Sajdlov et al., (2018), migratory is part of fish behavior. Vertically there are four zones, each zone has different proportions. (Figure 4).

High light intensity tends to make schooling fish spread (Syahputra et al., 2016), as evidenced by the high intensity, the schooling fish spreading out of the catchable area characterized by zones namely influence zone (IZ) and shadow zone (SZ) with $44 \%$ of IZ proportion in initial conditions, $15 \%$ of SZ, at 250 PWM value $28 \%$ of $I Z, 5 \%$ of SZ, when schooling fish outside the catchable area it is needed to reduce the light intensity (Dwipayana et al., 2018), while moderate intensity values 195, 145 and 95 PWM produce proportions like high intensity. Fish that have the good visual ability are also has good resolution to light space (Purbayanto et al., 2010).

The gathering fish in a catchable area can be caused by one of the light intensities (Kardi et al., 2019). Catchable area zone of which $\mathrm{CZ}$ and $\mathrm{MZ}$ with a proportion of $39 \%$, $30 \%$ and $42 \% \mathrm{CZ}$ at 250,95 and 5 PWM; while MZ with proportion of $40 \%, 46 \%$ and $46 \%$ at initial condition, 195 and 20 PWM (Figure 5). The light intensity with different PWM values can modify fish behavior patterns by migration (Barranco and Hughes, 2015).

The existence of schooling fish is important to be known as basic information for the application of the use of light intensity with the appropriate PWM value in the fishing technique of static lift net fisheries. In Figure 4 and 5 , it shows the area of schooling fish with the different proportion value of schooling fish based on changes of the PWM value by horizontally and vertically.

\section{Conclusion}

The RGB-LED can change the light intensity by the PWM value, each light intensity has a zone with different radium vertically and horizontally. Intensity changes directly affected the changes in fish behavior to approach, gather and fish movement. By knowing changes in fish behavior based on the light intensity, it can be modeled and developed to be used in fishing activities on SLN.

\section{References}

Bao, J., Jiang, H., Tian, X., Dong, S. 2014. Growth and Energy Budgets of Green and Red Type Sea Cucumbers Apostichopus japonicus (Selenka) under different light colors. Aquaculture. $\underline{418}$ (1): 139-14.

Barranco, C.C., Hughes, L.E. 2015. Effects of light pollution on the emergent fauna of shallow marine ecosystems: Amphipods as a case study. Marine Pollution Bulletin. 94: 235-240

Brown, A., Rengi, P. 2014. Pelagic Fish Stock Estimation by Using The Hydroacoustic Method in Bengkalis Regency Waters. Jurnal Terubuk. :21- 34.

Brown, A., Yani, A.H., Hernando, W. 2016. Composition of trap catches which is operate in sea waters contain fish apartment in teluk rhu village waters, 
rupat utara sub district of bengkalis district. Jurnal Perikanan dan Kelautan. 21 (2): 55-64.

Cahyadi, C., You, X. 2016 Arrangement of led lumen based on pulse width modulation (pwm) betha version to attract the schooling fish. Jurnal kelautan nasional. 11 (2) 119-125

Celi, M., Filiciotto, F., Maricchiolo, G., Genovese, L., Maria Quinci, E., Maccarrone, V., Mazzola, S., Vazzana, M., Buscaino, G., 2016. Vessel noise pollution as a human threat to fish: assessment of the stress response in gilthead sea bream (Sparus aurata, Linnaeus 1758). Fish Physiol Biochem. 42 (2), 631-641.

Chairunnisa,S., Setiawan N., Irkham., Ekawati., K., Anwar A., Fitri A.D.P. 2018. Study of Fish Behavior with AUTO-LION Prototype, (Laboratorium Scale) Marine Fisheries. 9 (1): 53-62.

Dey, S., Ghosh, S. ,Debbarma, C., Sarkar, P., Marfai, M., Maiti, S., Jerram, D.A., 2011. jPOR: An ImageJ macro to quantify total optical porosity from blue-stained thin sections. Comput Geosci. 37, 18501859.

Dufour, M.R., Mayer, C.M., Qian, S.S., Vandergoot, C.S., Kraus, R.T., Kocovsky, P.M., Warner, D.M. 2018. Inferred Fish Behavior its Implication For Hydroacoustic Surveys in Nearshore Habitats. Fisheries Research. 99 : 63-75.

Dwipayana, M.F., Rostini, I., Apriliani, I.M. 2018. Results of floating capture tools with different hauling times in east beach pangandaran water. Jurnal Perikanan dan Kelautan. 9(1) : 112-118.

Faizah, K. 2017. Estimation of porosity extension in digital fibermate images (vynil alcohol) with software imagej $14.7 \mathrm{v}$. Jurnal Agroteknose. 9(2): 27-35.

Flare, R.S., Davie, A., Grant, B., Carboni, S., Atack, T., Migayd, H. 2016. Effects of light spectrum and tank background colour on atlantic cod (Gadus morhua) and turbot (Scophthalmus maximus) larvae performance. Aquaculture. 450 (1): 6-13.
Fore, M., Frank, K., Dempster, T., Alfredsen, J.A., Hoy, E. 2017. Biomonitoring Using Tagged Sentinel Fish and Acoustic Telemetry in Commercial Salmon Aquaculture: A Feasibility Study. Aquacultural Engineering. 78 : 163-172.

Fujaya, Y. 2002. Fish physiology Proyek Peningkatan Penelitian Pendidikan Tinggi Direktorat Jendral Pendidikan Tinggi. Departemen Pendidikan Nasional. Jakarta. Hal. 160-163

Guo, A., Yuan, Y., Chu, T., Lian Q. 2019. Hydroacoustic assessment of fish resources in three reservoirs: The effects of different management strategies on fish density, biomass and size. Fisheries Research. 215 : 90-96.

Himan, M.I., Mawardi, M., Diniah, Zulkarnain. 2018. Effectiveness of Submersible LED Light as Hauling Lamp on Boat Liftnet. Albacore. 2 (1): 069-077

Im, S., Park, S.G., Cho, Y., Sung, H.J. 2018. Schooling Behavior of Rigid and Flexible Heaving Airfoils. International Journal of Heat and Fluid Flow. 69: 224-233.

Kadir, I.A., Susanto, A.N., Karman, A., Ane, I.O. 2019. Status of fisheries sustainability of boat lift net based on bio-economy in toniku village west Halmahera District. Jurnal IImu dan Teknologi Kelautan Tropis. 11 (1): 181-190.

Loupatty, G. 2012. Analisis Warna Cahaya Lampu Terhadap Hasil Tangkapan Ikan. Jurnal Barekeng. 6(1):47-49.

Manik, H.M. 2015. Measurement and numerical model of fish target strength for quantitative echo sounder. AACL Bioflux.8(5): 699-70

Manik, H.M., Mamum, A., Hestirianoto, T. 2014. Computation Of Single Beam Echo Sounder Signal For Underwater Objects Detection And Quantification. International Journal of Advanced Computer Science and Applications. 5(5): 94-97.

Mekdara, P.J., Schwalbe, M.A.B., Coughlin, L.L., Tytell, E.D. 2018. The Effects Of Lateral Line Ablation and Regeneration in Schooling Giant Danios. Journal of Experimental Biology. 226. Jeb. 175166 doi:10.1242/jeb.175166.

Nabiu, N.L.M., Baskoro, M.S., Yusfiandayani, R. 2018. Light adaptation process of retinal yellowstripe scad (Selaroides 
leptolepsis. Jurnal Teknologi Perikanan dan Kelautan. 9 (1): 97-102.

Palawe, H.J., Kaparang, F.E., Luasunaung, A., Silooy, F., Sompie, M.S. 2019. Effects of colored blinking led on squid catch rates in Tahuna waters Kelurahan Santiago Kabupaten Kepulauan Sangihe. Jurnal IImu dan Teknologi Perikanan Tangkap. 3(3): 110-114

Parra HE, Pham CK, Menezes GM, Rosa A, Tempera F, Morato T. 2017. Predictive Modeling of Deep-Sea Fish Distribution in the Azores. Deep-Sea Research II. 145: 49-60.

Penggabean, D. 2011. Analisis Swimming Layers dan Sebaran Senditas Ikan Pelagis Kecil di Selat Makassar. [tesis]. Bogor (ID): Institut Pertanian Bogor.

Purbayanto A, Riyanto M, Fitri ADP. 2010. Fisiologi dan tingkah laku ikan pada perikanan tangkap. Bogor (ID): IPB Press.

Ramadhan, B., Rosana, N., Sofijanto, M.A. 2018. Analysis of tancap charts composition result using the soil wave based fishing tools in delegan water, Gresik east Jawa Seminar Nasional Kelautan XIII.

Rand, P.S., Fukushima, M. 2014. Estimating the size of the spawning population and evaluating environmental controls on migration for a critically endangered Asian salmonid, Sakhalin taimen. Ecology and Conservation. 2 : 214-225

Sajdlov, Z.,Frouzov, J., Drastik, V., Juza, T., Peterka, J., Prchalova, M., Riha, M., Vasek, M., Kubecka, J., Cech, M. 2018. Are diel vertical migrations of European perch (Perca fluviatilis L.) early juveniles under direct control of light intensity? Evidence from a large field experiment. Freshwater Biology. 63:473-482

Smott, S., Monczak, A., Miller, M.E., Mantie, E.W. 2018. Boat noise in an estuarine soundscape - A potential risk on the acoustic communication and reproduction of somniferous fish in the May River, South Carolina. Marine Pollution Bulletin. 133: 246-260.

Syahputra, R.D., Bambang, A.N., Ayunita, D.N.N.D. 2016. Technical and Financial Analysis Comparison between Stationery Lift Nett and Raft Lift Nett in Muncar Coastal Fishing Port, Banyuwangi, East
Java. Journal of Fisheries Resources Utilization Management and Technology. 5 (4): 206-215.

Takahashi, A., Kasagi, S., Murakami, N., Furufuji, S., Kikuchi, S., Mizusawa, K., Andoh, T. 2018. Effects of different green light intensities on the growth performance and endocrine properties of barfin flounder verasper moseri. General and Comparative Endocrinology. 257 (1): 203-210.

Urbasa, F., Kaparang, F.E., Kumajas, H.J. 2015. Study of fish interest in floating net cages to the color of light in Sindulang I waters, Tuminting District, Manado City. Jurnal IImu dan Teknologi Perikanan Tangkap. 2: 39-43.

Willianmson, B., Fraser, S., Williamson, L., Nikora, V., Scott, B. 2019. Predictable changes in fish school characteristics due to a tidal turbine support structure. Renewable Energy. 141: 1092-1102.

Zielkea, L., Vierratha, S., Moronia, R., Mondonc, A., Zengerlea, R., Thiele, S., 2016. Three-dimensional morphology of the interface between micro porous layer and catalyst layer in a polymer electrolyte membrane fuel cell. Royal Society of Chemistry. 6. 80700-80705. 